\title{
Studi Bioakumulasi Logam Crom (Cr), Seng (Zn) dan Nikel (Ni) pada Tanaman Obat Binahong (Anredera cordifolia (Ten) Steenis.)
}

\author{
Zaeni, A. ${ }^{1^{*}}$, Ambardini, S. $^{2}$, Sartinah, A. ${ }^{3}$, Ramadhani, A.N. ${ }^{3}$, Sartini ${ }^{3}$, Amin, A. ${ }^{3}$, Patiung, G.W. ${ }^{1}$, \\ Susilowati, P.E. ${ }^{1}$ \\ ${ }^{1}$ Jurusan Kimia, FMIPA, Universitas Halu Oleo, Kendari \\ 2Jurusan Biologi FMIPA, Universitas Halu Oleo, Kendari \\ ${ }^{3}$ Jurusan Farmasi, F. Farmasi, Universitas Halu Oleo, Kendari \\ *alamat email korespondensi : zaeni@yahoo.com
}

\begin{abstract}
The use of traditional medicines based on medicinal plants has now grown rapidly. The use of medicinal plants has increased with increasing public awareness of consuming medicines made from medicinal plant raw materials, due to the assumption that drugs derived from plants are safer and have far less side effects than synthetic drugs. Plants have the ability to accumulate heavy metals that are found in the places where they grow. This study aims to determine the effect of the addition of heavy metal concentrations of $\mathrm{Cr}, \mathrm{Zn}$ and Ni on metal growth and accumulation in plants. The research with the binahong medicinal plant nursery and then grown on soil media containing heavy metals with varying concentrations and without the addition of heavy metal (control). Heavy metal content of was analysis using Atomic Absorption Spectroscopy (AAS) method. Metal accumulation in the binahong plant is known through the value of the Bioaccumulation Factor and the Translocation Factor. The addition of $\mathrm{Cr}, \mathrm{Zn}, \mathrm{Ni}$ metal concentrations affected plant growth as indicated by a decrease in the average number of plant leaves. Binahong plants are a $\mathrm{Cr}, \mathrm{Zn}$ and $\mathrm{Ni}$ acumulators with BAF values $>1$. The translocation ability of $\mathrm{Cr}$ metal with $\mathrm{TF}$ values between 0.202-0.427 on stems and 0.628-0.699 on leaves. The translocation ability of Zn metal with TF values between 0.812-1.233 on stems and 0.612-0.693 on leaves. The translocation ability of $\mathrm{Ni}$ metal with $\mathrm{TF}$ valueat the root 1;0.40-0.49 on the stem and 0.530.6 on the leaves.
\end{abstract}

Keywords: Anredera cordifolia (Ten) Steenis.; Bioaccumulation; Crom; Zink; Nickel

\begin{abstract}
Abstrak
Penggunaan obat tradisional berbahan dasar tanaman obat saat ini telah berkembang pesat. Pemanfaatan tanaman obat mengalami peningkatan dengan meningkatnya kesadaran masyarakat untuk mengkonsumsi obat dari bahan baku tanaman obat, karena asumsi bahwa obat yang berasal dari tanaman lebih aman dan efek sampingnya jauh lebih kecil dibandingkan obat sintetik. Tanaman memiliki kemampuan mengakumulasi logam berat yang terdapat pada tempat tumbuhnya. Penelitian ini bertujuan untuk mengetahui pengaruh penambahan konsentrasi logam berat $\mathrm{Cr}$, Zn dan Ni terhadap pertumbuhan dan akumulasi logam pada tanaman. Penelitian diawali dengan pembibitan tanaman obat binahong
\end{abstract}


kemudian ditumbuhkan pada media tanah yang mengandung logam berat dengan variasi konsentrasi serta tanpa penambahan logam berat (kontrol). Kandungan logam berat dianalisis menggunakan metode Spektroskopi Serapan Atom (SSA). Akumulasi logam pada tanaman binahong diketahui melalui nilai Faktor Bioakumulasi dan Faktor Translokasi. Penambahan konsentrasi logam Cr, Zn, Ni mempengaruhi pertumbuhan tanaman ditunjukkan dengan penurunan rata-rata jumlah daun tanaman. Tanaman binahong merupakan akumulator $\mathrm{Cr}, \mathrm{Zn}$ dan Ni dengan nilai BAF > 1. Kemampuan translokasi logam Cr dengan nilai TF antara 0,202-0,427 pada batang dan 0,628-0,699 pada daun. Kemampuan translokasi logam Zn dengan nilai TF antara 0,812-1,233 pada batang dan 0,612-0,693 pada daun. Kemampuan translokasi logam Ni dengan nilai TF pada bagian akar 1; 0.40-0.49 pada batang dan 0.53-0.6 pada daun.

Kata Kunci : Binahong; Bioakumulasi; Krom; Seng; Nikel

\section{Pendahuluan}

Indonesia merupakan salah satu negara yang memiliki sumber daya alam yang melimpah. Keanekaragaman sumber daya tersebut terlihat dari kelimpahan flora dan fauna yang hidup di daratan Indonesia, salah satunya tanaman obat. Terdapat sekitar 30.000 jenis tanaman dan 7000 diantaranya memiliki khasiat obat (Jumiarni \& Komalasari, 2017). Pengobatan tradisional yang berlandaskan sumber alam hayati terutama tumbuhtumbuhan alam, telah digunakan sejak lama di Indonesia. Pengetahuan tentang tanaman berkhasiat obat berdasar pada pengalaman yang terus diwariskan dari generasi ke generasi. Obat tradisional banyak dipilih karena memiliki keunggulan, diantaranya bahan mudah didapat, murah, hampir tidak memiliki efek samping (Haryoto et al., 2015). Saat ini penggunaan obat bahan alam cenderung terus meningkat dari tahun ke tahun. Kebanyakan masyarakat saat ini kembali menggunakan obat tradisional dikarenakan adanya asumsi bahwa sesuatu yang alami pasti tidak berbahaya.

Tanaman obat bisa dimanfaatkan dalam berbagai bentuk, yaitu penggunaan langsung untuk bumbu dapur, bahan baku makanan dan minuman, obat tradisional dan kosmetik. Pemanfaatan tanaman obat sebagai bahan baku obat tradisional dan jamu, dikarenakan tanaman ini mempunyai kandungan metabolit sekunder sifat spesifik, yang menyebabkan dapat bersifat pencegahan (preventif) dan promotif. Peningkatan tersebut didorong oleh perkembangan ilmu pengetahuan dan teknologi yang menyediakan informasi pemanfaatan obat bahan alam,

Salah satu tanaman yang saat ini banyak digunakan masyarakat dalam pengobatan herbal adalah binahong (Anredera cordifolia 
Zaeni, dkk. Akta Kimia Indonesia 6(1), 2021, 12-27

(Ten.) Steenis). Khasiat tanaman binahong secara empiris telah diketahui, antara lain sebagai obat penyembuh luka, wasir, penyakit tiphus, radang usus, asam urat dan disentri (Fitriyah, 2013) (Samirana et al., 2016). Binahong merupakan salah satu spesies famili Basellaceae yang banyak dimanfaatkan oleh masyarakat dalam pengobatan. Seluruh bagian tanaman ini dapat digunakan dalam terapi herbal seperti umbi, batang, bunga, dan daun. Pengetahuan mengenai khasiat tanaman binahong akan mendorong pengembangan tanaman ini sebagai salah satu produk obat herbal Indonesia.

Suatu tanaman obat dapat digunakan sebagai bahan baku obat, dengan syarat memenuhi standar World Health Organization (WHO). Untuk tanaman yang berkhasiat dalam pengobatan yang akan digunakan sebagai bahan baku produk, adalah harus terbebas dari kontaminasi logam berat (Jena, 2012). Kualitas dan keamanan bahan baku tanaman obat sangat dipengaruhi oleh faktor internal genetik dan faktor eksternal, yaitu lingkungan tumbuh, budidaya, cara panen, proses pascapanen, pengangkutan dan penyimpanan.

Faktor lingkungan saat ini menjadi perhatian serius dengan meningkatnya tingkat pencemaran lingkungan. Cemaran pada tanaman obat dapat berupa logam berat. Konsentrasi logam berat dalam tanah dan air beberapa tahun terakhir dilaporkan terus meningkat, akibat makin banyaknya pabrik dan kegiatan pertambangan dapat mengakibatkan penurunan kualitas tanah dan kualiatas tanaman obat. Bahan pencemar yang biasa terdapat di lingkungan adalah logam berat. Logam berat merupakan unsur logam yang mempunyai massa jenis lebih tinggi yakni lebih besar dari $5 \mathrm{~g} / \mathrm{cm}^{3}$, seperti $\mathrm{Cd}, \mathrm{Hg}, \mathrm{Pb}, \mathrm{Zn}$, dan Ni. Logam berat merupakan bahan pencemar yang berbahaya karena bersifat toksik jika terdapat dalam jumlah besar (Irhamni et al., 2017). Logam berat dapat menimbulkan efek terhadap kesehatan bagi manusia. Kontaminasi oleh logam berat menjadi perhatian serius karena dapat mencemari tanah maupun air serta dapat menyebar ke daerah sekitarnya melalui air, angin dan terakumulasi.

Logam berat dalam tanah pada keadaan bebas dengan konsentrasi tinggi dapat bersifat racun. Kondisi tersebut selain akan mempengaruhi ketersediaan hara tanaman juga dapat mengkontaminasi hasil tanaman. Jika logam berat memasuki lingkungan tanah, maka akan terjadi keseimbangan dalam tanah kemudian akan terserap oleh tanaman 
Zaeni, dkk. Akta Kimia Indonesia 6(1), 2021, 12-27

melalui akar, dan selanjutnya akan terdistribusi ke bagian tanaman lainnya (Haryoto et al., 2015). Kandungan logam di dalam tanah dapat mempengaruhi jumlah kandungan logam pada tanaman yang tumbuh diatas tanah tersebut. Kandungan logam pada tanaman akan berdampak pada jumlah dan kualitas hasil pertanian termasuk kualitas bahan baku obat yang berasal dari tanaman, serta secara tidak langsung akan berdampak buruk pada kesehatan manusia terkhusus lagi bagi penggunaan obat tradisional.

Hasil penelitian menemukan salah satu dari lima produk obat herbal (ayurveda) yang di produksi di Asia Selatan dan tersedia di toko di Boston mengandung timbal, merkuri, dan arsen pada tingkat yang berpotensi membahayakan (Saper et al., 2004). Toksisitas logam dikaitkan dengan penggunaan produk obat herbal Ayurveda, seperti enselofati bayi, kelumpuhan bawaan, tuli sensoneural. Sejak 1978, diketahui setidaknya 55 kasus keracunan logam berat terkait dengan produk obat herbal Ayurveda terjadi pada orang dewasa dan anak-anak telah dilaporkan di Amerika Serikat. Contoh kasus lain ialah penelitian yang dilakukan oleh Husna dkk (2015) mengenai kemungkinan cemaran logam berat $(\mathrm{Pb})$, kadmium (Cd), dan merkuri $(\mathrm{Hg})$ dalam salah satu produk jamu pegal linu yang diperjualbelikan di kota Pekanbaru. Hasilnya patut menjadi perhatian karena dari analisis yang dilakukan menunjukkan kandungan logam $\mathrm{Pb}$ dan $\mathrm{Hg}$ pada jamu telah melampaui ambang batas yang diperbolehkan BPOM RI, sedangkan logam Cd nilainya masih di bawah standar BPOM RI.

Logam berat krom ( $\mathrm{Cr}$ ) merupakan salah satu logam berat yang bersifat racun pada kadar tertentu. Logam $\mathrm{Cr}$ terdapat di alam secara bebas, tetapi sebagai logam pencemar dihasilkan akibat aktivitas manusia. Krom mudah menembus membran sel dan akan terjadi reduksi didalamnya. Faktor utama terjadinya toksisitas dari krom adalah oxidation state dan daya larutnya (Prayudi, Moh. et al., 2015). Kemudahan krom terlarut ke dalam air akan menyebabkan logam ini dengan mudah tersebar ke perairan dan memasuki lingkungan tanah sehingga berpotensi untuk terakumulasi oleh mahkluk yang hidup di area tersebut (Nuraini et al., 2017). Krom mudah menembus membran sel dan akan terjadi reduksi di dalamnya.

Zn secara alami terdapat di alam bebas seperti di udara, tanah, air dan makanan. Sebagian besar penambahan $\mathrm{Zn}$ berasal dari kegiatan industri seperti penambangan, 
Zaeni, dkk. Akta Kimia Indonesia 6(1), 2021, 12-27

batubara, pembakaran limbah dan pemrosesan baja, juga dari penggunaan pupuk dan pestisida (Arora, 2017). Seng adalah mikronutrien yang memiliki peran struktural dan katalitik utama dalam banyak protein dan enzim yang terlibat dalam proses metabolisme. Seng juga berperan pada biosintesis klorofil dan karotenoid yang bermanfaat sebagai proses fotosintesis. Seng relatif tidak beracun, terutama jika dikonsumsi secara oral. Namun, konsumsi Zn jumlah berlebih dapat menyebabkan disfungsi sistem yang mengakibatkan penurunan pertumbuhan dan reproduksi.

Nikel merupakan suatu mikronutrien yang dibutuhkan oleh tanaman, untuk pertumbuhannya. Peran logam $\mathrm{Ni}$ dalam tanaman adalah aktivator beberapa enzim pada tanaman, seperti hidrogenase, urease, asetil-S-koenzim A sintase, peptide deformilase, karbon monoksida dehidrogenase, dan glioksalase I (Mulrooney dan Hausinger, 2003). Logam Ni diserap oleh tanaman melalui transport aktif dan difusi pasif. Difusi pasif akan meningkat dengan meningkatnya konsentrasi $\mathrm{Ni}$ pada tanah (Seregin et al., 2014). Pada manuia, sejumlah kecil nikel digunakan oleh tubuh untuk menghasilkan sel darah merah, namun nikel akan berbahaya ketika melebihi jumlah yang ditoleransi oleh tubuh (Al-fartusie \& Mohssan, 2017).

\section{Metode Penelitian}

2.1 Pembuatan Tanah Terkontaminasi logam berat

Tanah bersih ditimbang $2 \mathrm{Kg}$ sebagai media tanam yang akan diberi perlakuan, kemudian dicampurkan dengan larutan $\mathrm{Cr}, \mathrm{Zn}$ dan $\mathrm{Ni}$, pada berbagai variasi konsentrasi.

\subsection{Pembibitan dan pemeliharaan tanaman} Pembibitan dilakukan dengan menanam secara stek. Tanaman yang telah ditanam pada media tanah terkontaminasi, diberi perlakuan dengan disiram sebanyak 2 kali sehari (pagi dan sore hari). Tiap hari tanaman disiram menggunakan air sehingga cukup membasahi tanah. Tanaman dihindarikan dari hujan.

\subsection{Pertambahan Jumlah Daun Tanaman}

Penghitungan jumlah daun dilakukan tiap hari. Jumlah daun dihitung pada daun tanaman yang telah membuka sempurna.

\subsection{Pengukuran Kandungan Logam}

Analisis kandungan logam logam berat dilakukan menggunakan metode spektrofotometri serapan atom. Akumulasi logam pada tanaman binahong dihitung melalui nilai faktor bioakumulasi dan faktor 
Zaeni, dkk. Akta Kimia Indonesia 6(1), 2021, 12-27

translokasi. Faktor Bioakumulasi atau Bioaccumulation Factor (BAF) menggunakan rumus (Radulescu dkk., 2013): $B A F=\frac{C_{P}}{C_{t}}$. Keterangan: $\mathrm{BAF}=$ Bioaccumulation Factor, $\mathrm{Cp}=$ konsentrasi logam pada bagian tanaman, $\mathrm{Ct}=$ konsentrasi awal logam pada media tanah. Faktor Translokasi atau Translocation Factor (TF) menggunakan rumus berikut (Radulescu dkk., 2013): Nilai TF dihitung menggunakan rumus berikut: $T F=$ $\frac{C p}{C r}$. Keterangan: $\mathrm{TF}=$ Faktor Translokasi; $\mathrm{Cp}=$ Konsentrasi logam pada bagian tanaman; $\mathrm{Cr}=$ Konsentrasi logam pada bagian akar tanaman.

\section{Hasil dan Pembahasan}

Binahong merupakan tanaman menjalar yang bersifat parenial (berumur panjang) dengan tinggi lebih dari $6 \mathrm{~m}$. Akar tunggang berwarna cokelat membentuk umbi dan lunak. Batang tidak berkayu, tidak berair, bentuk silindris, saling membelit, permukaan halus, warna merah, bagian dalam padat, kadang membentuk semacam umbi yang melekat di ketiak daun dengan bentuk tak beraturan dan bertekstur kasar. Daun tunggal, bertangkai sangat pendek, tersusun berseling, berwarna hijau, bentuk jantung, panjang 5-10 cm, lebar 3-7 cm, helaian daun tipis lemas, ujung runcing, pangkal berlekuk, tepi rata, permukaan licin, bisa dimakan (Gambar 1)

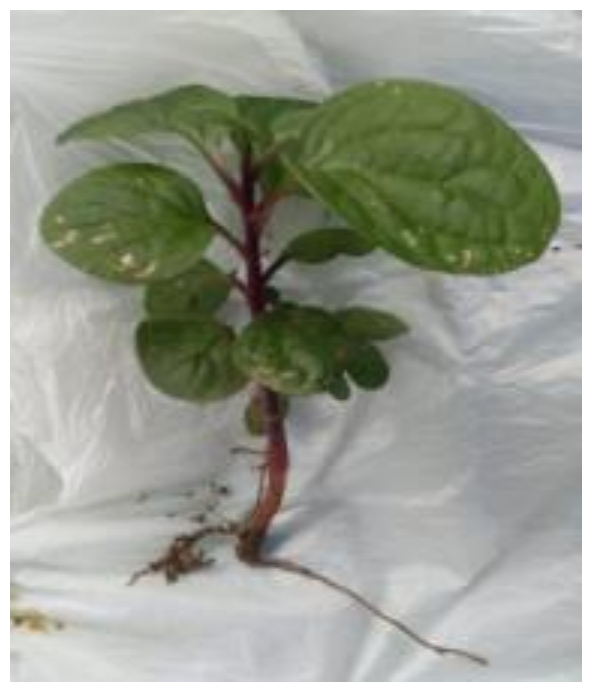

Gambar 1. Tanaman Binahong (Anredera cordifolia (Ten) Steenis). Sumber : Dokumentasi Pribadi 
Zaeni, dkk. Akta Kimia Indonesia 6(1), 2021, 12-27

\subsection{Pertumbuhan Tanaman Binahong}

Pertumbuhan tanaman merupakan suatu proses bertambahnya ukuran dan bobot tanaman yang disebabkan oleh bertambahnya ukuran organ tanaman (Baskoro, 2011). Pertumbuhan bersifat kuantitatif dan tidak dapat balik lagi (irreversible). Pertumbuhan suatu tanaman dapat ditunjukkan melalui banyak parameter diantaranya, pertambahan volume (tinggi, panjang, dan luas), pertambahan jumlah daun (Rismawati, 2012). Pengamatan pertumbuhan tanaman binahong dilakukan selama 30 hari dengan mengamati jumlah daun tanaman, serta perubahan lain yang dapat dilihat pada batang maupun pada daun tanaman binahong.

Pengaruh penambahan konsentrasi logam berat pada jumlah daun tanaman binahong ditunjukan pada Gambar 2. Berdasarkan data tersebut, terlihat adanya pengaruh penambahan konsentrasi logam krom, seng dan nikel terhadap rata-rata jumlah daun tanaman, yakni semakin tinggi konsentrasi logam yang diberikan maka rata-rata jumlah daunnya semakin berkurang (Gambar 2). Semakin tinggi logam yang ditambahkan, maka terlihat tidak mengalami pertambahan daun dan terjadi pengurangan jumlah daun secara signifikan. Kondisi ini terjadi pada penambahan logam Cr 60 ppm, Zn 100 ppm, dan Ni 100 ppm (Gambar 2).

Gangguan pertumbuhan pada tanaman disebabkan karena tanaman telah menyerap logam dari media tanam dan telah metranslokasikan ke bagian jaringan tanaman yang lain. Setelah logam masuk ke dalam jaringan tanaman, logam dapat berikatan dengan protein atau enzim yang dapat menyebabkan gangguan dalam metabolisme tanaman. Sehingga proses pertumbuhan pada tanaman dapat terganggu. Kondisi ini dapat dilihat dari gejala yang terdapat pada tanaman melalui proses klorosis pada daun, ujung batang menghitam dan kemudian tanaman akan layu dan mengalami kematian.

\subsection{Penyerapan Logam Berat oleh Tanaman} Binahong

Tanaman dengan penambahan konsentrasi logam $\mathrm{Cr} 20$ ppm dan 40 ppm sudah mengalami keguguran daun, meskipun masih mampu bertahan hidup dengan cukup baik hingga hari terakhir perlakuan (Gambar 2). Kondisi ini menunjukan keberadaan logam $\mathrm{Cr}$ di dalam tanah mempengaruhi laju pertumbuhan, yakni jumlah daun. Kematian tanaman memberikan gambaran tanaman binahong tidak mampu mentoleransi konsentrasi logam krom pada media tanam. 
Zaeni, dkk. Akta Kimia Indonesia 6(1), 2021, 12-27

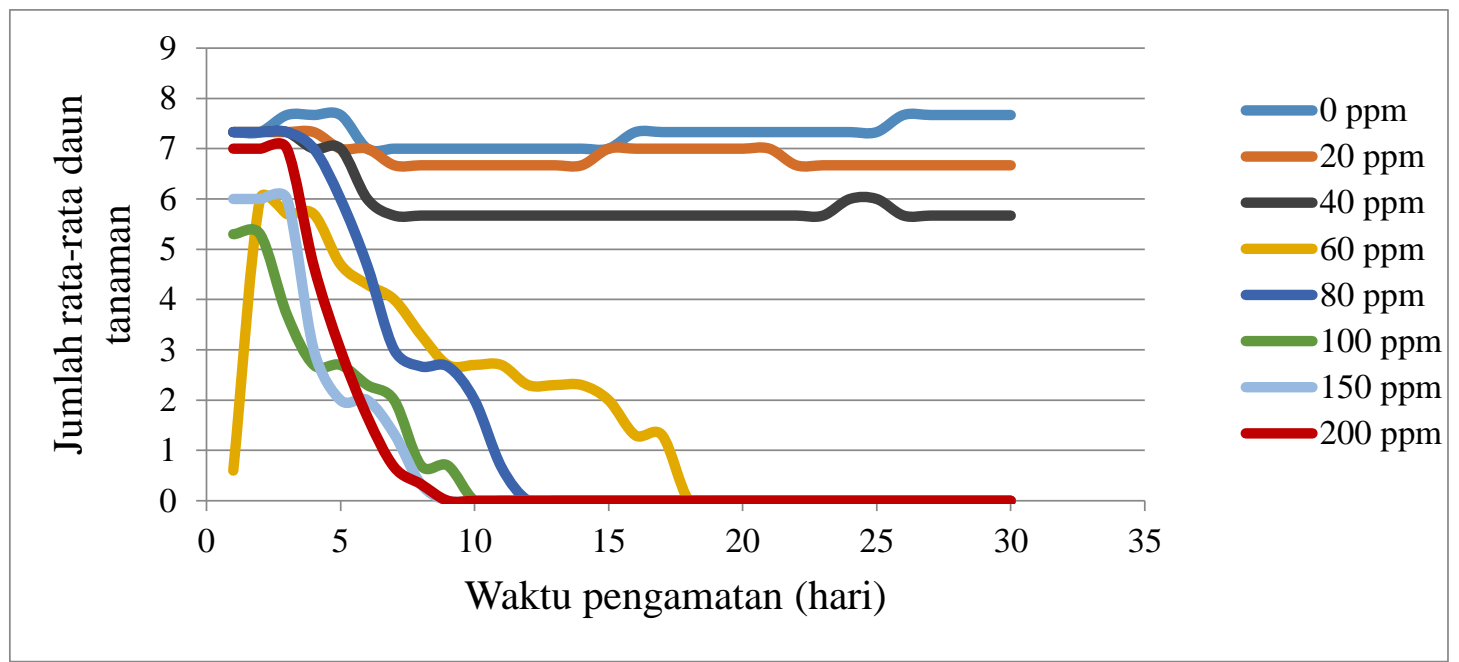

(A)

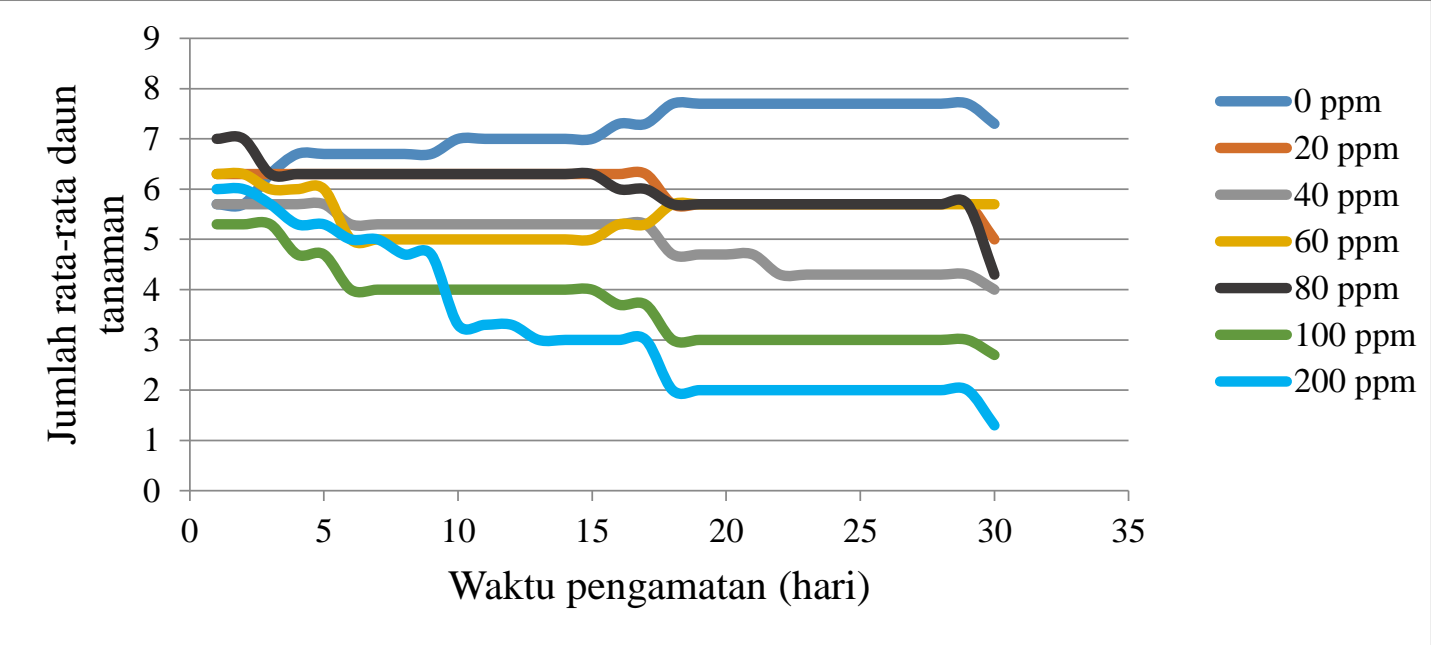

(B)

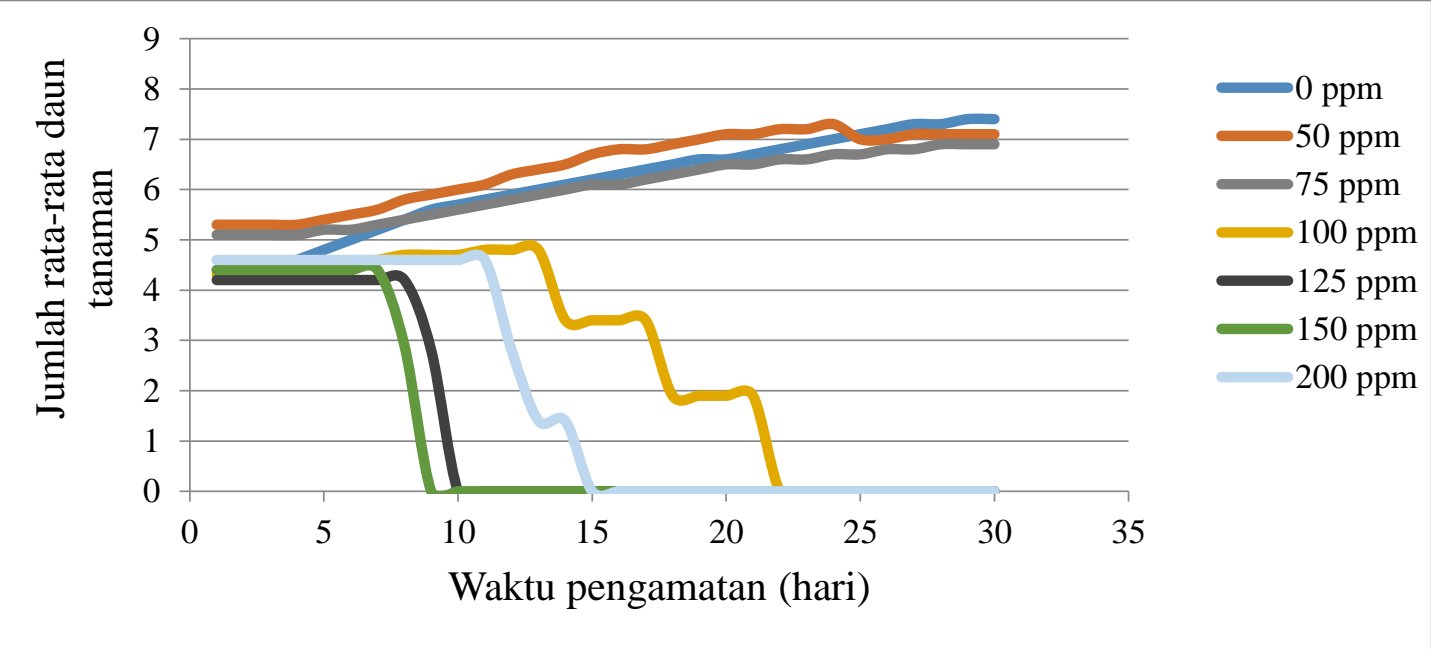

(C)

Gambar 2. Pengaruh Penambahan Logam Berat terhadap Rata-rata Jumlah Daun Tanaman Binahong. Keterangan: A: Logam Cr; B: Logam Zn; C: Logam Ni. 
Zaeni, dkk. Akta Kimia Indonesia 6(1), 2021, 12-27

Kematian tanaman terjadi ketika logam $\mathrm{Cr}$ yang diserap ke dalam sel secara pasif melalui pertukaran kation pada dinding sel. Masuknya $\mathrm{Cr}$ ke dalam sel tanaman berakibat Cr akan terikat dengan protein dan juga dapat berinteraksi dengan asam nukleat sehingga akan mengganggu proses metabolisme sel. Menurut (Ciscato et al., 1999), logam berat seng dalam jumlah tinggi dapat menghambat aktivitas enzim $\alpha$-amilase, ATPase, fitase dan IAA (Indol Acetic Acid) oksidase yang merupakan hormon perangsang multiplikasi tanaman. Konsentrasi logam $\mathrm{Zn}$ yang tinggi berpengaruh terhadap tanaman yaitu dapat menghambatan proses fotosistem I dan fotosistem II, yaitu mengganggu mekanisme perpindahan $\mathrm{Mg}$ pada hidrolisis di fotosistem II. Akibat selanjutnya proses pertumbuhan tanaman akan terganggu hingga menyebabkan kematian. Tanaman yang tumbuh pada media tanah dengan penambahan Zn masing-masing 100 ppm dan 200 ppm mengalami trend pengurangan jumlah rata-rata daun yang konsisten hingga hari ke-30 pengamatan, di mana pengurangan jumlah rata-rata daun pada perlakuan Zn 200 ppm lebih besar. Hal ini menunjukkan pengaruh yang nyata dari kuantitas cemaran logam Zn terhadap pertumbuhan tanaman (Gambar 2).
Penambahan konsentrasi $\mathrm{Zn}$ pada media tanam yang lebih rendah (di bawah 80 ppm), menyebabkan tanaman mampu mentoleransi hingga hari ke-30 (Gambar 2). Toleransi tanaman binahong terhadap logam seng disebabkan pada konsentrasi tertentu logam berat seng dibutuhkan untuk pertumbuhan tanaman. Peran logam berat Zn adalah sebagai kofaktor beberapa enzim yang mengatur pertumbuhan. Pada tanaman, logam berat seng berfungsi mengaktifkan beberapa enzim, seperti dehidrogenase, aldolase, isomerase, transfosforilase, RNApolimerase, DNA-polimerase.

Tanaman secara umum menempatkan logam berat dalam akar, batang dan daun. Hasil pengukuran konsentrasi logam $\mathrm{Cr}$ dan $\mathrm{Ni}$ pada tanaman binahong, menunjukkan akumulasi terbesar logam berat terjadi pada bagian akar (Tabel 1). Sedangkan akumulasi logam $\mathrm{Zn}$ tertinggi terjadi pada batang (Tabel 1). Faktor yang mempengaruhi akumulasi terbesar terjadi pada akar tanaman untuk logam $\mathrm{Cr}$ dan $\mathrm{Ni}$, disebabkan akar merupakan jaringan tanaman yang kontak langsung dengan media tanah mengandung logam sehingga berpotensi lebih besar dalam menyerap logam. Untuk akumulasi logam Zn terbesar pada batang, diduga karena $\mathrm{Zn}$ berperan dalam mensintesis hormon auksin 
Zaeni, dkk. Akta Kimia Indonesia 6(1), 2021, 12-27

yang banyak terdapat pada bagian batang dan akar tanaman.

Adanya akumulasi logam berat ( $\mathrm{Cr}, \mathrm{Zn}$ dan $\mathrm{Ni})$ pada tanaman kontrol (tanpa penambahan logam berat pada media tanam), mengindikasikan tanah yang digunakan telah mengandung logam berat, namun berdasarkan hasil tersebut (Tabel 1) dapat memberikan informasi bahwa penambahan logam $\mathrm{Cr}, \mathrm{Zn}$ dan $\mathrm{Ni}$ pada media tanam meningkatkan penyerapan logam tersebut oleh tanaman binahong. Kandungan logam $\mathrm{Cr}, \mathrm{Zn}$ dan Ni pada tanaman menggambarkan tanaman binahong memiliki sifat indikator terhadap logam $\mathrm{Cr}$, Zn, dan Ni.

Tabel 1. Kandungan Logam Berat pada Bagian Tanaman Binahong

\begin{tabular}{cccc}
\hline $\begin{array}{c}\text { Konsentrasi logam Pada } \\
\text { Media Tanam (ppm) }\end{array}$ & Konsentrasi yang Terserap pada Bagian Tanaman (ppm) \\
\cline { 2 - 4 } Krom (Cr) & Batang & Daun \\
\hline 0 & 70,933 & 17,063 & 51,325 \\
\hline 20 & 108,747 & 22,036 & 68,360 \\
\hline 40 & 255,227 & 109,099 & 178,458 \\
\hline Seng (Zn) & & & 12.995 \\
\hline 0 & 23,518 & 85,5951 & 139.509 \\
\hline 20 & 227,852 & 185,174 & 153.510 \\
\hline 40 & 231,907 & 228.013 & 39.147 \\
\hline Nikel (Ni) & & & 74.149 \\
\hline 0 & 60.436 & 35.524 & 109.19 \\
\hline 50 & 124.290 & 81.686 & \\
\hline 75 & 204.220 & 99.468 & \\
\hline
\end{tabular}

Semua bagian tanaman binahong yaitu daun, batang dan akarnya dalam pengobatan tradisional digunakan sebagai obat. Batas cemaran logam krom yang diizinkan oleh WHO dalam tanaman obat adalah $1,5 \mathrm{mg} / \mathrm{kg}$ (Shah, dkk., 2013). Berdasarkan data yang diperoleh kandungan logam $\mathrm{Cr}$ pada daun binahong dengan penambahan logam $\mathrm{Cr}$ pada media tanam tanah, melebihi batasan yang diperbolehkan WHO, sehingga perlu diperhatikan media tanam tanah yang akan digunakan untuk menanam tanaman binahong untuk digunakan sebagai bahan baku obat. 
Zaeni, dkk. Akta Kimia Indonesia 6(1), 2021, 12-27

Bahayanya logam Zn, adalah bila asupan Zn dalam tubuh melebihi 100 mg/hari dapat menyebabkan toksisitas, sehingga menyebabkan antara lain gangguan penurunan sistem imunitas, anemia, pengurangan kadar HDL (High Density Lipoprotein) kolesterol di dalam darah. Namun Zn juga diperlukan dalam jumlah sedikit oleh sel tubuh mahluk hidup termasuk tubuh manusia. Diketahui $\mathrm{Zn}$ dapat menstimulasi aktivitas 100 macam enzim dan terlibat sebagai kofaktor pada 200 jenis enzim lainnya (Ambarwati, 2012); (Mulyaningsih, 2013).

Jika dirata-ratakan kandungan logam Ni pada bagian akar, batang dan daun tanaman binahong yang ditanam pada media dengan penambahan nikel 0 ppm, 50 ppm dan 75 ppm berturut-turut adalah 135,108 mg/kg; $280,129 \mathrm{mg} / \mathrm{kg}$ dan $412.88 \mathrm{mg} / \mathrm{kg}$ seperti pada Tabel 1. Environmental Protection Agency (EPA) merekomendasikan asupan harian Ni harusnya kurang dari 1 mg (Khan et al., 2015). Berdasarkan jumlah tersebut menunjukkan kandungan logam nikel pada tanaman binahong melebihi batas yang diperbolehkan.

\subsection{Kemampuan Akumulasi Logam}

Besarnya akumulasi logam berat oleh tanaman juga dikaitkan dengan nilai
Bioaccumulation Factor (BAF) dan

Translocation Factor (TF). Nilai BAF

(Bioaccumulation Factor) menunjukkan kemampuan suatu tanaman untuk mengakumulasi logam pada bagian tanaman terhadap konsentrasi logam pada media tanah. Nilai TF (Translocation Factor) menggambarkan kemampuan tanaman dalam mentranslokasikan logam dari akar ke bagian jaringan tanaman yang lain. Nilai TF > 1 menunjukkan bahwa tanaman sangat efektif dalam mentranslokasikan logam berat dari akar ke bagian tanaman (batang dan daun) (Sekabira dkk., 2011).

Tanaman yang memiliki nilai $\mathrm{BAF}<1$ di kategorikan sebagai tanaman ekskluder, yaitu tanaman yang mencegah logam berat memasuki bagian tanaman lain namun konsentrasi di sekitar perakaran masih tinggi. Nilai BAF 1-10, menunjukan tanaman bersifat akumulator (tanaman yang menyerap logam pada jaringan bagian atas tanaman, sehingga kadar logam di jaringan mencerminkan kadar logam di dalam tanah). Sedangkan bila nilai BAF > 10, maka tanaman digolongkan hiperakumulator (tanaman yang dapat mentolerir logam berat pada konsentrasi yang tinggi dan tanaman dapat berkembang di tanah terkontaminasi logam). Tanaman dimasukan kelompok akumulator, bila 
Zaeni, dkk. Akta Kimia Indonesia 6(1), 2021, 12-27

mempunyai nilai $B A F>1$, excluder mempunyai nilai $\mathrm{BAF}<1$, dan indikator mempunyai nilai $B A F=1$ (Susana \& Lingki-jngan, 2013).
$\mathrm{BAF}$, menunjukkan akumulasi logam $\mathrm{Cr}$ lebih banyak pada bagian akar $>$ daun $>$ batang (Tabel 2).

Hasil analisis kandungan logam krom pada masing-masing perlakuan berdasarkan nilai

Tabel 2. Nilai BAF dan TF sampel tanaman binahong yang tumbuh pada media tanah mengandung logam berat

\begin{tabular}{|c|c|c|c|}
\hline Sampel & $\begin{array}{l}\text { Konsentrasi logam } \\
\text { pada media (ppm) }\end{array}$ & BAF & TF \\
\hline \multicolumn{4}{|l|}{ Krom (Cr) } \\
\hline \multirow{3}{*}{ Akar } & 0 & - & - \\
\hline & 20 & 5,437 & - \\
\hline & 40 & 6,380 & - \\
\hline \multirow{3}{*}{ Batang } & 0 & - & - \\
\hline & 20 & 1,101 & 0,202 \\
\hline & 40 & 2,727 & 0,427 \\
\hline \multirow{3}{*}{ Daun } & 0 & - & - \\
\hline & 20 & 3,418 & 0,628 \\
\hline & 40 & 4,461 & 0,699 \\
\hline \multicolumn{4}{|l|}{ Seng (Zn) } \\
\hline \multirow{3}{*}{ Akar } & 0 & - & - \\
\hline & 20 & 11,392 & - \\
\hline & 40 & 5,799 & - \\
\hline \multirow{3}{*}{ Batang } & 0 & - & - \\
\hline & 20 & 9,258 & 0,812 \\
\hline & 40 & 5,700 & 0,982 \\
\hline \multirow{3}{*}{ Daun } & 0 & - & - \\
\hline & 20 & 6,975 & 0,612 \\
\hline & 40 & 3,837 & 0,661 \\
\hline \multicolumn{4}{|l|}{ Nikel } \\
\hline \multirow{3}{*}{ Akar } & 0 & - & - \\
\hline & 50 & 2.4859 & 1 \\
\hline & 75 & 2.7229 & 1 \\
\hline \multirow{3}{*}{ Batang } & 0 & - & - \\
\hline & 50 & 1.63 & 0.40 \\
\hline & 75 & 1.33 & 0.49 \\
\hline \multirow{3}{*}{ Daun } & 0 & - & - \\
\hline & 50 & 1.48 & 0.6 \\
\hline & 75 & 1.46 & 0.53 \\
\hline
\end{tabular}


Zaeni, dkk. Akta Kimia Indonesia 6(1), 2021, 12-27

Tabel 3. Persentase pengurangan jumlah rata-rata daun tanaman binahong masingmasing perlakuan (pengamatan 30 hari)

\begin{tabular}{|c|c|c|c|}
\hline \multicolumn{3}{|c|}{ Penambahan logam krom (Cr) } \\
\hline \multirow{2}{*}{ Konsentrasi (ppm) } & \multicolumn{2}{|c|}{ Jumlah rata-rata daun } & \multirow{2}{*}{ Pengurangan (\%) } \\
\cline { 2 - 3 } & Hari ke 1 & Hari ke 30 & 100,00 \\
\hline 60 & 6 & 0 & 100,00 \\
\hline 100 & 5,3 & 0 & \\
\hline
\end{tabular}

\begin{tabular}{|c|c|c|c|}
\hline \multirow{2}{*}{ Konsentrasi (ppm) } & \multicolumn{2}{|c|}{ Penambahan logam seng (Zn) } \\
\cline { 2 - 3 } & Hari ke 1 & Hari ke 30 & \multirow{2}{*}{ Pengurangan (\%) } \\
\hline 60 & 6,3 & 5,7 & 9,52 \\
\hline 100 & 5,3 & 3 & 43,40 \\
\hline
\end{tabular}

\begin{tabular}{|c|c|c|c|}
\hline \multicolumn{4}{|c|}{ Penambahan logam nikel (Ni) } \\
\hline \multirow{2}{*}{ Konsentrasi (ppm) } & \multicolumn{2}{|c|}{ Jumlah daun } & \multirow{2}{*}{ Pengurangan (\%) } \\
\cline { 2 - 3 } & Hari ke 1 & Hari ke 30 & $-33,96$ \\
\hline 50 & 5,3 & 7,1 & 100 \\
\hline 100 & 4,3 & 0 & \\
\hline
\end{tabular}

Nilai BAF > 1 terdapat pada akar, daun dan batang tanaman. Tanaman binahong termasuk selompok akumulator untuk logam krom (nilai BAF > 1). Sedangkan kemampuan translokasi logam $\mathrm{Cr}$ dengan nilai TF antara $0,202-0,427$ pada batang dan 0,628-0,699 pada daun. Nilai TF lebih kecil dari 1 (Tabel 2) untuk batang dan daun, kondisi ini menunjukan logam krom terakumulasi.

Nilai TF untuk logam Zn pada konsentrasi 2040 ppm pada bagian daun dan batang lebih kecil dari 1 (Table 2), menunjukkan terjadi translokasi logam yang rendah pada bagian tanaman ini. Nilai BAF di akar, batang dan daun lebih besar dari 1 (Tabel 2). Nilai BAF untuk logam Zn di bagian akar tanaman menunjukan tanaman binahong termasuk kelompok hiperakumulator (nilai BAF > 10) (Tabel 2). Berdasarkan nilai TF pada bagian batang dan daun pada konsentrasi 20-40 ppm, menunjukkan tanaman tanaman binahong memiliki kecenderungan melakukan translokasi yang rendah untuk logam Zn (nilai TF kurang dari 1) (Tabel 2).

Berdasarkan data Tabel 2, diketahui bahwa logam Ni terakumulasi lebih banyak pada bagian akar tanaman binahong. Nilai BAF dari setiap perlakuan adalah lebih besar dari 1 
Zaeni, dkk. Akta Kimia Indonesia 6(1), 2021, 12-27

yang menunjukkan bahwa tanaman binahong merupakan tanaman yang bersifat akumulator logam Ni. Nilai TF logam nikel pada bagian batang dan daun lebih kecil dari 1 yang menunjukkan bahwa translokasi logam yang rendah pada bagian tersebut. Nilai TF pada bagian akar sama dengan 1 menunjukkan bahwa logam banyak terakumulasi pada bagian akar.

Pemantauan pengurangan jumlah rata-rata daun tanaman binahong setelah hari ke-30 ditunjukkan pada Tabel 3.

\section{Kesimpulan}

Tanaman binahong dapat menyerap logam $\mathrm{Cr}, \mathrm{Zn}, \mathrm{Ni}$ sehingga mempengaruhi pertumbuhan tanaman dengan menurunnya jumlah daun. Tanaman binahong merupakan kelompok tanaman akumulator untuk logam krom dan nikel (nilai BAF > 1) Tanaman binahong merupakan tanaman hiperakumulator terhadap logam seng, dengan nilai $\mathrm{BAF}>10$.

\section{Daftar Pustaka}

[1] Al-fartusie, F. S., \& Mohssan, S. N. (2017). Indian Journal of Advances in Chemical Science Essential Trace Elements and Their Vital Roles in Human Body. Indian Journal of Advances in Chemical Science,
5 , 127-136. https://doi.org/10.22607/IJACS.2017.503 003

[2] Ambarwati, R. (2012). Peran zinc terhadap peningkatan sistem imunitas. Jurnal Keperawatan, V(2), 98-103.

[3] Arora, S. (2017). Review of Heavy Metal Contamination in Soil. International Journal of Environmental Sciences \& Natural Resources, 3(5). https://doi.org/10.19080/ijesnr.2017.03. 555625

[4] Ciscato, M., Vangronsveldb, J., \& Valcke, R. (1999). Effects of Heavy Metals on the Fast Chlorophyll Fluorescence Induction Kinetics of Photosystem II : a Comparative Study.

[5] Haryoto, Sujono, T. A., \& Suhendi, Andi, M. (2015). Pengembangan Potensi Herbal Medicine Dari Ekstrak Tumbuhan Sala ( Cynometra ramiflora Linn .) Menjadi Obat Herbal Terstandar: Uji Farmakologi, Toksisitas dan Penyelidikan Kimia. University Research Colloquium, 46-63.

[6] Husna, L. O., Hanifah, A. T \& Kartika, F.G. (2015). Analisis Kandungan Logam Timbal, Kadmium dan Merkuri Dalam Produk Jamu Pegal Linu Yang Beredar Di Kota Pekanbaru. Jurnal Ilmiah Mahasiswa. 2(1), 130-135. 
[7] Irhamni, Pandia, S., Purba, E., \& Hasan, W. (2017). Serapan Logam Berat Esensial dan Non Esensial pada Air Lindi TPA Kota Banda Aceh Dalam Mewujudkan Pembangunan Berkelanjutan. Serambi Engineering, $\quad$ I(3), 134-140. https://ojs.seramhttps//ojs.serambimekk ah.ac.id , index.php , jse , article , download

[8] Jena, V. (2012). Study of Heavy Metal Distribution in Medicinal Plant Basil. Journal of Environmental \& Analytical Toxicology, $\quad$ 02(08), 8-10. https://doi.org/10.4172/21610525.1000161

[9] Jumiarni, W. O., \& Komalasari, O. (2017). Eksplorasi Jenis Dan Pemanfaatan Tumbuhan Obat Pada Masyarakat Suku Muna Di Permukiman Kota Wuna. Traditional Medicine Journal, 22(1), 4556.

[10] Khan, M. U., Muhammad, S., Malik, R. N., \& Khan, S. A. (2015). Human and Ecological Risk Assessment: An International Heavy metals potential health risk assessment through consumption of wastewater irrigated wild plants: A case study. October. https://doi.org/10.1080/10807039.2015. 1056292
[11] Mulrooney, S. B., \& Hausinger, R. P. (2003). Nickel uptake and utilization by microorganisms. FEMS Microbiology Reviews, 27(2-3), 239-261. https://doi.org/10.1016/S0168-

6445(03)00042-1

[12] Mulyaningsih, T. R. (2013). Kandungan Unsur Fe dan Zn Dalam Bahan Pangan Produk Pertanian, Peternakan dan Perikanan Dengan Metode k 0 - AANI. Jurnal Sains Dan Teknologi Nuklir Indonesia, $\quad$ 10(2), 71-80. http://jurnal.batan.go.id/index.php/jstni /article/viewFile/651/579

[13] Nuraini, R. A. T., Endrawati, H., \& Maulana, I. R. (2017). Analisis Kandungan Logam Berat Kromium (Cr) Pada Air, Sedimen Dan Kerang Hijau (Perna viridis) Di Perairan Trimulyo Semarang. Jurnal Kelautan Tropis, 20(1), 48. https://doi.org/10.14710/jkt.v20i1.1104

[14] Prayudi, Moh., T. A., Zubair, A., \& Maricar, I. (2015). FITOREMEDIASI TANAH TERCEMAR LOGAM Cr DENGAN TUMBUHAN AKAR WANGI PADA MEDIA TANAH BERKOMPOS. Jurnal Fitoremediasi, 1(2), 1-24.

[15] Samirana, Swastini, Subratha, \& Ariadi. (2016). Uji Aktivitas Penyembuhan Luka Ekstrak Etanol Daun Binahong 
Zaeni, dkk. Akta Kimia Indonesia 6(1), 2021, 12-27

(Anredera scandens (L.) Moq.) pada Tikus Jantan Galur Wistar. Jurnal Farmasi Udayana, $5(2)$, $19-23$.

https://simdos.unud.ac.id/uploads/file_p enelitian_1_dir/2474ecb0794a663ad550 ff6e3c77ab10.pdf.

[16] Saper, R., Kales, S. N., Paquin, J., Burns, M. J., Eisenberg, D. M., Davis, R. B., \& Phillips, R. S. (2004). Ayurvedic Herbal Medicine Products. Journal of American Medical Association, 292(23), 2868-2873. http://www.iss.it/binary/farm/cont/Ayur vedic.1103533632.pdf
[17] Seregin, I. V., Erlikh, N. T., \& Kozhevnikova, A. D. (2014). Nickel and zinc accumulation capacities and tolerance to these metals in the excluder Thlaspi arvense and the hyperaccumulator Noccaea caerulescens. Russian Journal of Plant Physiology, 61(2), 204-214.

https://doi.org/10.1134/S102144371402 0137

[18] Susana, R., \& Lingki-jngan, M. D. A. N. (2013). Diteliti. 20(2), 221-228. 